\title{
Anti-inflammatory effect of natural heterocycle glucoside vicine obtained from Vicia faba L. and its aglucone (divicine) and their effect on some oxidative stress biomarkers in Albino rats
}

\author{
Mohammed Abdalla Hussein ${ }^{1^{*}}$ \\ ${ }^{1 *}$ Department of Biochemistry, Faculty of Pharmacy, October $6^{\text {th }}$ University, October $6^{\text {th }}$ city, Egypt
}

Submission Date: 26-1-2012; Revised Date: 15-3-2012; Accepted Date: 22-4-2012

\begin{abstract}
Background: Inflammation is typically characterized by increased permeability of endothelial tissue resulting in oedema. Much of pyrimidine derivatives have been highly useful for treating acute and self-limited inflammatory conditions. This study was performed to explore the acute toxicity, anti-inflammatory activity and biochemical effect of natural heterocycle pyrimidine glucoside vicine obtained from Vicia faba L. and its aglucone (divicine) and their effect on some oxidative stress biomarkers in Albino rats. Also, the anti-inflammatory effect of the tested compounds were compared with diclofenac sodium (100 mg/ $\mathrm{kg} \mathrm{bw})$. On the other hand, this article was extended to assess the impact of a very high dose of diclofenac sodium $(100 \mathrm{mg} / \mathrm{kg}$ bw) on liver enzymes, which was used by many authors to explain the negative effects of diclofenac when used at this dose as a standard anti-inflammatory drug. Methods: The median lethal dose $\left(\mathrm{LD}_{50}\right)$ and histopathological effects of vicine and divicine was determined in order to assess their safety. Also, the inflammatory effect of the tested compounds was examined at doses (50-200 mg/ $\mathrm{kg} \mathrm{bw}$ ) in rats, using fresh egg albumin-induced oedema and compared with standard anti-inflammatory drugs, diclofenac sodium $(100 \mathrm{mg} / \mathrm{kg} \mathrm{bw})$. Finally, vicine and divicine treatment $(50-200 \mathrm{mg} / \mathrm{kg} \mathrm{bw})$ was evaluated for 10 consecutive days prior in Albino rats in the serum levels of hepatic enzymes, glutamate oxaloacetate transaminase (GOT), glutamate pyruvate transaminase (GPT), gamma glutamyl transferase ( $\gamma$-GT), alkaline phosphatase (ALP), lactate dehydrogenase $(\mathrm{LDH})$, super oxide dismutase (SOD), reduced glutathione (GSH), glutathione peroxidase (GPx) and thiobarbituric acid reactive substances (TBARs). Results: Vicine and divicine were found to have an $\mathrm{LD}_{50}$ of 2100 and $1950 \mathrm{mg} /$ $\mathrm{kg}$ bw orally, respectively and a significant $(\mathrm{p}<0.001)$ dose-dependent anti-inflammatory activity with the highest percentage inhibition (59.56\%) and (45.65\%) for vicine and divicine, respectively, at $150 \mathrm{mg} / \mathrm{kg}$ against the fresh egg albumin-induced oedema in rats after $180 \mathrm{~min}$. Also, the standard anti-inflammatory diclofenac sodium (100 mg/kg) showed 100\% inhibition against the fresh egg albumin-induced oedema in rats after 180 minutes. In addition, administration of vicine and divicine orally to the rats at doses of $50-200 \mathrm{mg} / \mathrm{kg}$ bw for 10 days showed non-significant changes in liver enzymes and serum TBARs as compared with the control group. But administration of diclofenac sodium orally at a concentration of $100 \mathrm{mg} / \mathrm{kg}$ bw daily for 10 consecutive days to rats showed significant increase in liver enzymes and serum TBARs and significant decrease in blood GSH, SOD and GPx. Histopathology of the rat liver morphology of all the treated groups showed no disorder except for the photomicrograph of the cross section of liver from rats treated with diclofenac sodium $100 \mathrm{mg} / \mathrm{kg}$ for 10 consecutive days, shows pronounced dilatation of the hepatic portal vein. Conclusion: The observation allows conclusion that vicine and divicine at concentration of $50-150 \mathrm{mg} / \mathrm{kg}$ bw exhibited good anti-inflammatory effect and have no hepatotoxic activity.
\end{abstract}

Keywords: toxicity, anti-inflammatory, rats, vicine and divicine, fava beans (Vicia faba).

${ }^{*}$ Corresponding address:

Mohammed A. Hussein, Ph.D. Biochemistry department, Faculty of Pharmacy, October $6^{\text {th }}$ University, October $6^{\text {th }}$ City, Egypt.

Tel.: +2 (012) 4832580; fax: +2 (02) 38353270.

E-mail : abdallamohammed_304@yahoo.com

DOI: 10.5530/ax.2012.2.8

\section{INTRODUCTION}

Pyrimidine nucleus is one of the most important heterocycles exhibiting remarkable pharmacological activities. In medicinal chemistry, pyrimidine derivatives have been 


\section{Mohammed Abdalla Hussein: Anti-inflammatory effect of natural heterocycle glucoside vicine}

well known for their therapeutic applications. The presence of a pyrimidine base in thymine, cytosine and uracil, which are the essential building blocks of nucleic acids,
DNA and RNA is one of the possible reasons for their activities. ${ }^{[1]}$<smiles>Cc1c[nH]c(=O)[nH]c1=O</smiles>

Thymine<smiles>Nc1ccnc(=O)[nH]1</smiles>

Cytosine<smiles></smiles>

Uracil
Also, the pyrimidine ring is found in vitamins like riboflavin, thiamine and folic acid, ${ }^{[2]}$ barbituric acid and its several derivatives (e.g. Veranal) which are used as

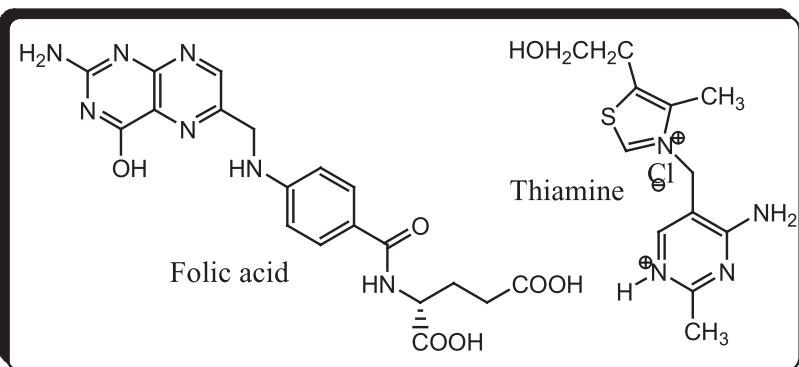

hypnotics $^{[3]}$ and in alloxan, which is known for its diabetogenic action in a number of animals. ${ }^{[4]}$<smiles>O=c1cc(O)[nH]c(=O)[nH]1</smiles>

Barbituric acid<smiles>O=C1NC(=O)C(=O)C(=O)N1</smiles>

Veranal<smiles>O=C1NC(=O)C(O)(O)C(=O)N1</smiles>

Alloxan
Pyrimidine has a remarkable pharmacological efficiency and therefore intensive research has been focused on the anti-inflammatory activity of pyrimidine nucleus. ${ }^{[5,6]}$ In addition, pyrimidine nucleus is also present in certain natural product sources such as vicine and divicine. Divicine is an aglycone derived from vicine, a glucosidic compound contained in fava beans.

Fava bean (Vicia faba; broad bean, horse bean) is an important member of the legume family with highly useful characteristics. It is widely grown and consumed, especially in China, North African countries and parts of Europe and North and South America, and is served in a large variety of forms, mostly based on the immature or mature seed. The highest concentration of vicine or divicine in fava beans was found in young seeds. The concentration decreased rapidly with maturity of seeds or the whole pod. ${ }^{[7]}$ Also, vicine isolated from certain medicinal plants is used in folk medicine for various ailments, ${ }^{[8]}$ the hypoglycemic properties could be verified as well as in animals as in humans. ${ }^{[9]}$ In addition to this effect, it is used for treating stomach ache, colds and fevers, rheumatism, gout and to introduce abortion. Also, it has been described as a blood purifier, laxative and antihelmintic. ${ }^{[10]}$

Diclofenac, a non-steroidal anti-inflammatory drug (NSAID), is commonly employed in the treatment and/or management of rheumatoid arthritis and

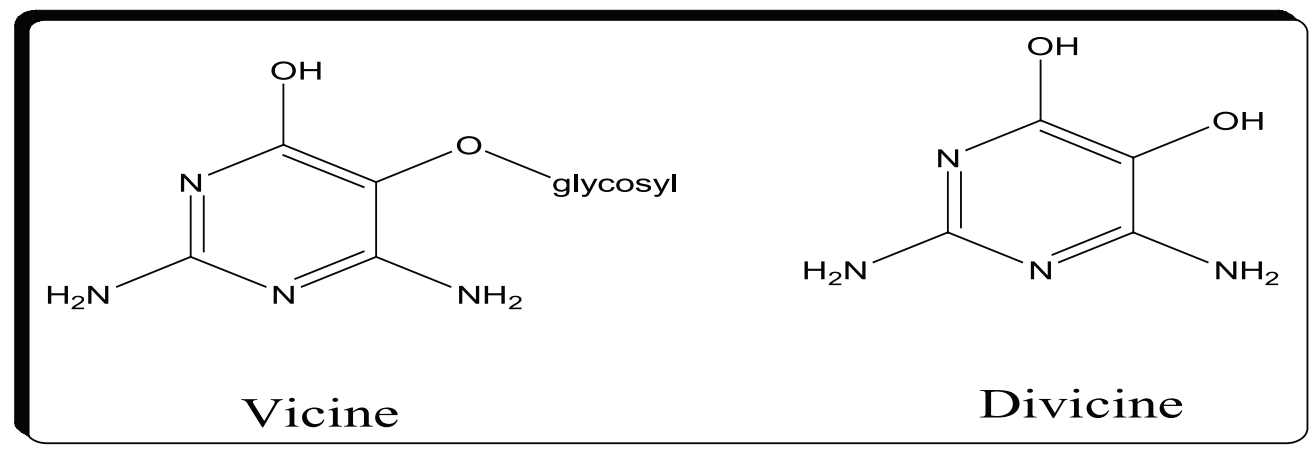

Figure 1. Structural formulas of vicine and divicine in $V$. faba. 


\section{Mohammed Abdalla Hussein: Anti-inflammatory effect of natural heterocycle glucoside vicine}

osteo-arthritis ${ }^{[11,12]}$ and for its anti-inflammatory and analgesic effects. ${ }^{[13]}$ Diclofenac sodium reduces inflammation, swelling and arthritic pain by inhibiting prostaglandins synthesis and/or production. ${ }^{[14,15]}$ The drug also affects polymorphonuclear leukocytes function in vitro, thereby reducing chemotaxis, superoxide toxic radical formation, oxygen-derived free radical generation and neutral protease production. ${ }^{[16]}$ Diclofenac sodium has also been reported to suppress inflammation in experimental animal models. ${ }^{[17]}$ As an extension of my interested research program in the extraction and therapeutic evaluation of medicinal plants, ${ }^{[18-21]} \mathrm{I}$ report herein, a facile route to calculate the median lethal doses $\left(\mathrm{LD}_{50}\right)$ and describe the anti-inflammatory effect of vicine and divicine isolated from fava beans (Vicia faba) which may pave the way for possible therapeutic application.

\section{MATERIALS AND METHODS}

\section{Chemistry}

Melting points were determined on Gallen-kamp melting point apparatus and are uncorrected. The infrared (IR) spectra were recorded on shimadzu MR 470 infrared spectrophotometer using the $\mathrm{KBr}$ pellets. Microanalytical data $(\mathrm{C}, \mathrm{H}, \mathrm{N})$ was determined at the Microanalytical Centre, Cairo University, Egypt. Mass spectra were run using HP Model MS-5988.

Tested compounds

1. Vicine pure crystalline sample was extracted from mature seeds of fava beans (Vicia faba) according to the procedure described by Arbid and Marquardt. ${ }^{[2]}$

2. Divicine pure crystalline sample was obtained by acid hydrolysis from vicine according to the method described by Marquarott et al. ${ }^{[23]}$

\section{METHODS}

\section{Animals}

Male adult Albino rats weighing between 150-170 gm were obtained from the animal house Cairo University, Faculty of Veterinary Medicine. The animals were maintained on a $12 \mathrm{~h} \mathrm{light/dark} \mathrm{cycle} \mathrm{with} \mathrm{ad} \mathrm{labium}$ access to food (commercial diet) during all periods of this study.

\section{Determination of $\mathrm{LD}_{50}$}

Preliminary experiments were carried out for each tested compound on 6 main groups (10 rats/each dose/each group). Vicine and divicine were administrated orally in different doses to find out the range of doses which cause zero and $100 \%$ mortality of animals. A range dose was determined for each compound.

I used 120 rats divided into 12 main groups of 10 animals. In groups $1-6$, of 10 animals each, $\mathrm{LD}_{50}$ of vicine was calculated by giving an oral dose of 700, 1400, 2100, 2800, 3500 and $4200 \mathrm{mg} / \mathrm{kg}$ bw, corresponding each dose to one group of 10 animals. In a similar way, in groups $7-12, \mathrm{LD}_{50}$ of divicine was determined by oral administration of the following doses: 500, 1000, 1500, 2000, 2500 and $3000 \mathrm{mg} / \mathrm{kg}$ bw.

The $\mathrm{LD}_{50}$ was evaluated by Spearman and Karber method $^{[24]}$ on groups of rats, each of 10 animals. The test compounds were administrated orally at different doses. The number of animals which died within $24 \mathrm{~h}$ was recorded. The $\mathrm{LD}_{50}$ was then calculated by the application of the following formula:

$$
\mathrm{LD}_{50}=\mathrm{Dm}-\frac{\sum(\mathrm{Z} \cdot \mathrm{d})}{\mathrm{n}}
$$

$\mathrm{D}_{\mathrm{m}}=$ the dose which killed all the rats in the group

$\mathrm{Z}^{\mathrm{m}}=$ half the sum of the dead rats from 2 successive groups

$\mathrm{d}=$ the difference between 2 successive doses

$\mathrm{n}=$ number of animals in each group

\section{Evaluation of anti-inflammatory property}

The rats used were divided into five broad (A, B, C, D and E) experimental groups. All groups were injected in the right paw with albumin $(0.5 \mathrm{ml} / \mathrm{kg} \mathrm{sp})$.

Group A (8 rats) control untreated group (neither treated with vicine nor divicine).

Group B (8 rats) received distilled water (3 $\mathrm{ml} / \mathrm{kg}$ orally) only.

Group C 'test' (consisted of 4 sub groups, 8 rats in each subgroup) received vicine (50, 100, 150 and $200 \mathrm{mg} / \mathrm{kg}$ orally suspended in distilled water).

Group D 'test' (consisted of 4 subgroups, 8 rats in each subgroup) received divicine (50,100, 150 and $200 \mathrm{mg} / \mathrm{kg}$ orally suspended in distilled water).

Group E 'test' (8 rats) received diclofenac sodium $\left(100 \mathrm{mg} / \mathrm{kg}\right.$ orally suspended in distilled water). ${ }^{[25,26]}$

The rat hind paw oedema was used as a model of acute inflammation. Rat hind paw oedema was induced by intraplantar injection of fresh egg albumin $(0.5 \mathrm{ml} / \mathrm{kg}) \cdot{ }^{[2]}$ Oedema was always evident within 5-8 min following fresh egg albumin $(0.5 \mathrm{ml} / \mathrm{kg})$ injection. Linear diameter of the injected paw was measured (with a transparent 


\section{Mohammed Abdalla Hussein: Anti-inflammatory effect of natural heterocycle glucoside vicine}

millimeter ruler) for $3 \mathrm{~h}$ at 30-minute intervals after the administration of the fresh egg albumin. Increases in the linear diameter of the right hind paws were taken as indicators of paw oedema. Oedema was assessed in terms of the difference in the 'zero time' $\left(\mathrm{C}_{\mathrm{o}}\right)$ linear diameter of the injected right hind paw, and its linear diameter at 'time t' [(C) i.e., 30, 60, 90, 120 and $180 \mathrm{~min}]$ following fresh egg albumin administration. The increases in the right hind paw diameters induced by injections of fresh egg albumin were compared with those of the contra-lateral, noninjected left hind paw diameters. ${ }^{[28]}$ Vicine and divicine were separately administered at doses of 50, 100, 150 and 200 $\mathrm{mg} / \mathrm{kg}$ orally to each of the rats in the 'test' Groups $\mathrm{C}$ and $\mathrm{D}$, respectively, 20 min before inducing inflammation with the injection of fresh egg albumin. Rats in the reference, comparative 'test' Group E received diclofenac sodium $(100 \mathrm{mg} / \mathrm{kg}$ orally); while rats in the 'control' Group B received distilled water ( $3 \mathrm{ml} / \mathrm{kg}$ orally) only.

Percentage inhibition of the oedema was calculated from the formula:

$$
\left[\mathrm{I}_{\mathrm{o}}-\mathrm{I}_{\mathrm{t}} / \mathrm{I}_{\mathrm{o}}\right] \times 100
$$

[Where $\mathrm{I}_{\mathrm{o}}$ is the average inflammation (hind paw oedema) of the 'control' Group A rats at a given time; and $\mathrm{I}_{t}$ is the average inflammation of the (Groups $\mathrm{C}$ and/or D) vicine and/or divicine or (Group E) diclofenac-treated rats at the same time].

\section{BIOCHEMICAL STUDIES OF ANTI-INFLAMMATORY COMPOUNDS ON LIVER ENZYMES IN RATS}

\section{Experimental design}

This experiment was carried out to examine the effect of anti-inflammatory compounds, vicine and divicine on liver enzymes. A solution of 50, 100, 150 and $200 \mathrm{mg} / \mathrm{kg}$ bw for each anti-inflammatory compound, vicine and divicine suspended in saline was prepared for intragastric intubation of rats. Groups of animals each consisting of 8 rats in each were treated daily for 10 days as follows:

Group A: Normal Group (untreated group).

Group B: Control (was given similar volume of distilled water po).

Group $\mathrm{C}_{\mathrm{I}}$ : Was treated with vicine $(50 \mathrm{mg} / \mathrm{kg}$ bw) suspended in distilled water orally in a single daily dose. ${ }^{[29]}$

Group $\mathbf{C}_{\text {II }}$ : Was treated with vicine $(100 \mathrm{mg} / \mathrm{kg}$ bw) suspended in distilled water orally in a single daily dose. ${ }^{[29]}$

Group C $_{\text {III }}$ : Was treated with vicine $(150 \mathrm{mg} / \mathrm{kg}$ bw) suspended in distilled water orally in a single daily dose. ${ }^{[2]]}$

Group C $_{\mathrm{IV}}$ : Was treated with vicine $(200 \mathrm{mg} / \mathrm{kg} \mathrm{bw})$ suspended in distilled water orally in a single daily dose. ${ }^{[29]}$
Group $\mathbf{D}_{\mathrm{I}}$ : Was treated with divicine $(50 \mathrm{mg} / \mathrm{kg}$ bw) suspended in distilled water orally in a single daily dose. ${ }^{[2]}$ Group $\mathbf{D}_{\mathrm{II}}$ : Was treated with divicine $(100 \mathrm{mg} / \mathrm{kg}$ bw) suspended in distilled water orally in a single daily dose. ${ }^{[2]}$ Group $\mathbf{D}_{\mathrm{III}}$ : Was treated with divicine $(150 \mathrm{mg} / \mathrm{kg} \mathrm{bw})$ suspended in distilled water orally in a single daily dose. ${ }^{[29]}$ Group $\mathbf{D}_{\mathrm{IV}}$ : Was treated with divicine $(200 \mathrm{mg} / \mathrm{kg}$ bw) suspended in distilled water orally in a single daily dose. ${ }^{[29]}$ Group E: Was treated with diclofenac sodium $(100 \mathrm{mg} / \mathrm{kg}$ bw) suspended in distilled water orally in a single daily dose. $^{[29]}$

After 10 days of treatment, animals were killed by cervical dislocation, blood samples were withdrawn from the retro-orbital vein of each animal. The separated blood was used for the estimation of SGOT, SGPT, $\gamma$-GT, ALP, LDH, TBARS, GSH, GPx and SOD.

\section{BIOCHEMICAL ASSAYS}

Serum levels of glutamic-oxaloacetic transaminase (GOT) and glutamic-pyruvate transaminase (GPT) were determined according to Reitman and Frankel, ${ }^{[30]}$ alkaline phosphatase (ALP) was accessed according to King, ${ }^{[31]}$ Gamma Glutamyl transferase $\gamma$-GT was determined using the technique described by Fiala et al., ${ }^{[32]}$ lactate dehydrogenase was determined according to Buhl and Jackson ${ }^{[33]}$ and TBARS in serum was accessed according to Uchiyama and Mihara. ${ }^{[34]}$ Blood superoxide dismutase (SOD) and glutathione peroxidase (GPx) activities were determined using the technique described by Paglia and Valentine ${ }^{[35]}$ and Marklund and Marklund, ${ }^{[36]}$ respectively. Blood haemoglobin was accessed according to the method of Van Kampen and Zijlstra. ${ }^{[37]}$

\section{HISTOPATHOLOGY}

The liver tissues isolated from the test animals were fixed in formaline-saline for 48 hours. The fixed tissue were processed manually through graded ethanol, cleared in xylene, impregnated and embedded in paraffin wax. Thin sections were cut with a rotary microtome, stained by haematoxylin and eosin technique, examined microscopically for pathological changes according to the method of Bancroft and Steven. ${ }^{[38]}$

\section{DATA ANALYSIS}

Anti-inflammatory experimental data obtained from 'test' rats treated with vicine, divicine and diclofenac, as well as 


\section{Mohammed Abdalla Hussein: Anti-inflammatory effect of natural heterocycle glucoside vicine}

those obtained from distilled water-treated 'control' rats, were pooled and expressed as means \pm SD. The differences between vicine, divicine and diclofenac-treated 'test' means, and distilled water-treated 'control' means, were analyzed statistically by one way analysis of variance (ANOVA; 95\% confidence interval), followed by TukeyKramer's multiple comparison test to assess the level of significance of the differences between the 'test' and 'control' group data means. Values of $\mathrm{p} \leq 0.05$ were taken to imply statistical significance.

\section{RESULTS}

Table 1 shows the specific physicochemical properties of vicine and divicine. Melting point of vicine and divicine are 239-241 and 201-205, respectively. Microanalytical data in Table 1 shows that the calculate/found ratio of vicine and divicine $(\mathrm{C}, \mathrm{H}, \mathrm{N})$.

Infra red spectrum of vicine exhibited bands at 3331.9, $3309.6 \mathrm{~cm}^{-1}\left(\mathrm{NH}_{2}\right), 3201.6 \mathrm{~cm}^{-1}(\mathrm{OH}), 2908,2846 \mathrm{~cm}^{-1}$ (CH-aliphatic), $1680 \mathrm{~cm}^{-1}(\mathrm{C}=\mathrm{N}), 1473 \mathrm{~cm}^{-1}$ (C-O-C), $1218 \mathrm{~cm}^{-1}(\mathrm{C}-\mathrm{N}), 1064 \mathrm{~cm}^{-1}$ (C-O-C).

Mass spectrum of vicine revealed a molecular ion peak at $\mathrm{m} / \mathrm{z} 304(14.02 \%)$ with a base peak at $142(100 \%)$, and other significant peaks were observed at $162(15.71 \%)$, $90(15.46 \%), 81(15.65 \%)$.
Infra red spectrum of divicine exhibited bands at 3779.9, $3396 \mathrm{~cm}^{-1}\left(\mathrm{NH}_{2}\right), 2930,2846 \mathrm{~cm}^{-1}$ (CH-aliphatic), 1606 $\mathrm{cm}^{-1}(\mathrm{C}=\mathrm{N}), 1430 \mathrm{~cm}^{-1}$ (C-O-C), $1219 \mathrm{~cm}^{-1}(\mathrm{C}-\mathrm{N})$.

Mass spectrum of divicine revealed a molecular ion peak and a base peak at $\mathrm{m} / \mathrm{z} 143\left(\mathrm{M}^{+}+\mathrm{H}, 100 \%\right)$ and other significant peaks were observed at 138 (18\%), 130 (17.46\%), $90(15 \%), 87(19 \%)$.

\section{DETERMINATION OF LD $_{50}$ OF VICINE AND DIVICINE IN ADUULT RATS}

The results given in Table 2 show that oral administration of Vicine in doses of 700, 1400, 2100, 2800, 3500 and $4200 \mathrm{mg} /$ $\mathrm{kg}$ bw resulted in mortalities of $0,2,6,8,9$ and 10, respectively. The dose of vicine that killed half of the rats $\left(\mathrm{LD}_{50}\right)$ was $2100 \mathrm{mg} / \mathrm{kg}$ bw The results given in Table 3 show that oral administration of divicine in doses of 500, 1000, 1500, 2000, 2500 and $3000 \mathrm{mg} / \mathrm{kg}$ bw resulted in mortalities of $0,1,2,5$, 8 and 10, respectively. The dose of divicine that killed half of the rats $\left(\mathrm{LD}_{50}\right)$ was $1950 \mathrm{mg} / \mathrm{kg}$ bw.

\section{DETERMINATION OF ANTI-INFLAMMATORY ACTIVITY OF VICINE AND DIVICINE IN ADULT RATS}

The results presented in Table 4 shows that vicine (Group C) and divicine (Group D) (50-200 $\mathrm{mg} / \mathrm{kg}$ orally) produced

Table 1 Physico-chemical properties and molecular formulae of vicine and divicine

\begin{tabular}{|c|c|c|c|c|c|c|}
\hline \multirow[t]{3}{*}{ Compd. } & \multirow[t]{3}{*}{ M.P. $\left[{ }^{\circ} \mathrm{C}\right]$} & \multirow[t]{3}{*}{ Yield (\%) } & \multirow{3}{*}{$\begin{array}{l}\text { Mol. Formula } \\
\text { (Mol. Wt.) }\end{array}$} & \multicolumn{3}{|c|}{ Elemental analyses } \\
\hline & & & & \multicolumn{3}{|c|}{ Calcd./Found [\%] } \\
\hline & & & & C & $\mathrm{H}$ & $\mathbf{N}$ \\
\hline Vicine & $239-241$ & - & $\mathrm{C}_{10} \mathrm{H}_{16} \mathrm{~N}_{4} \mathrm{O}_{7}(304)$ & $\begin{array}{l}39.47 \\
39.25\end{array}$ & $\begin{array}{l}5.26 \\
5.30\end{array}$ & $\begin{array}{l}18.42 \\
18.30\end{array}$ \\
\hline Divicine & $201-203$ & 93 & $\mathrm{C}_{4} \mathrm{H}_{6} \mathrm{~N}_{4} \mathrm{O}_{2}(142)$ & $\begin{array}{l}33.80 \\
33.30\end{array}$ & $\begin{array}{l}4.23 \\
4.02\end{array}$ & $\begin{array}{l}39.43 \\
39.74\end{array}$ \\
\hline
\end{tabular}

Table 2 Determination of LD $_{50}$ of vicine given orally in adult rats

\begin{tabular}{|c|c|c|c|c|c|c|}
\hline Group Number & Dose (mg/kg) & $\begin{array}{l}\text { No. of animals/ } \\
\text { group }\end{array}$ & $\begin{array}{l}\text { No. of dead } \\
\text { animals }\end{array}$ & $(\mathrm{Z})$ & (d) & (Z.d) \\
\hline 1 & 700 & 10 & 0 & 1 & 700 & 700 \\
\hline 2 & 1400 & 10 & 2 & 4 & 700 & 2800 \\
\hline 3 & 2100 & 10 & 6 & 7 & 700 & 4900 \\
\hline 4 & 2800 & 10 & 8 & 8.5 & 700 & 5950 \\
\hline 5 & 3500 & 10 & 9 & 9.5 & 700 & 6650 \\
\hline 6 & 4200 & 10 & 10 & 0 & 00 & 00 \\
\hline
\end{tabular}

$$
\begin{aligned}
& \mathrm{LD}_{50}=\mathrm{Dm}-\frac{\sum(\mathrm{Z} \cdot \mathrm{d})}{\mathrm{n}} \\
& \mathrm{LD}_{50}=\frac{4200-21000}{10}=2100 \mathrm{mg} / \mathrm{kg} \mathrm{bw}
\end{aligned}
$$


Mohammed Abdalla Hussein: Anti-inflammatory effect of natural heterocycle glucoside vicine

Table 3 Determination of $\mathrm{LD}_{50}$ of divicine given orally in adult rats

\begin{tabular}{lccccrr}
\hline Group Number & Dose $\mathbf{( m g / k g )}$ & $\begin{array}{c}\text { No. of animals/ } \\
\text { group }\end{array}$ & $\begin{array}{c}\text { No. of dead } \\
\text { animals }\end{array}$ & (Z) & (d) & (Z . d) \\
\hline 1 & 500 & 10 & 0 & 0.5 & 500 & 250 \\
2 & 1000 & 10 & 1.5 & 3.5 & 500 & 750 \\
3 & 1500 & 10 & 2 & 6.5 & 500 & 1750 \\
4 & 2000 & 10 & 5 & 9.0 & 500 & 3250 \\
6 & 2500 & 10 & 10 & 0 & 4500 & 00 \\
\hline
\end{tabular}

$$
\begin{aligned}
& \mathrm{LD}_{50}=\mathrm{Dm}-\frac{\sum(\mathrm{Z} \cdot \mathrm{d})}{\mathrm{n}} \\
& \mathrm{LD}_{50}=\frac{3000-10500}{10}=1950 \mathrm{mg} / \mathrm{kg} \mathrm{bw}
\end{aligned}
$$

Table 4 Effects of vicine and divicine (50-200 mg/ kg, orally) and diclofenac sodium (DIC, $100 \mathrm{mg} / \mathrm{kg}$, orally) on rat paw oedema induced by fresh egg albumin $(0.5 \mathrm{ml} / \mathrm{kg} \mathrm{sp})$. Values quoted represent the mean $\pm \mathrm{SEM}$ of 8 observations. Percent inhibitions of the egg albumin-induced inflammation by vicine, divicine and reference drug

\begin{tabular}{|c|c|c|c|c|c|c|}
\hline \multirow{2}{*}{\multicolumn{2}{|c|}{$\begin{array}{c}\text { Experimental Group } \\
\text { Dose (orally) }\end{array}$}} & \multicolumn{5}{|c|}{ Time (in min) and paw diameter (in $\mathrm{mm}$ ) } \\
\hline & & 30 & 60 & 90 & 120 & 180 \\
\hline Cont & ip A (untreated) & $12.45 \pm 0.15$ & $12.32 \pm 0.42$ & $12.26 \pm 0.25$ & $12.30 \pm 0.31$ & $11.50 \pm 0.14$ \\
\hline Cor & $\begin{array}{l}\text { up B (distilled } \\
\text { ated) } 3 \mathrm{ml} / \mathrm{kg}\end{array}$ & $12.50 \pm 0.23$ & $12.40 \pm 0.25$ & $12.2 \pm 0.36$ & $12.35 \pm 0.49$ & $11.45 \pm 0.54$ \\
\hline \multirow{4}{*}{ 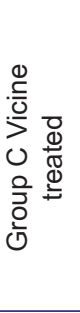 } & $50 \mathrm{mg} / \mathrm{kg}$ & $\begin{array}{c}11.08 \pm 0.14 \\
(12.36 \%)\end{array}$ & $\begin{array}{c}10.74 \pm 0.26 \\
(12.82 \%)\end{array}$ & $\begin{array}{l}9.35 \pm 0.19^{*} \\
(23.7 \%)\end{array}$ & $\begin{array}{l}9.09 \pm 0.34^{*} \\
(26.09 \%)\end{array}$ & $\begin{array}{l}9.95 \pm 0.25^{*} \\
(13.47 \%)\end{array}$ \\
\hline & $100 \mathrm{mg} / \mathrm{kg}$ & $\begin{array}{c}10.54 \pm 0.21 \\
(15.34 \%)\end{array}$ & $\begin{array}{l}9.27 \pm 0.13^{*} \\
(24.75 \%)\end{array}$ & $\begin{array}{l}8.84 \pm 0.25^{*} \\
(27.89 \%)\end{array}$ & $\begin{array}{l}7.05 \pm 0.22^{* *} \\
(42.68 \%)\end{array}$ & $\begin{array}{l}5.86 \pm 0.32^{* * *} \\
(49.04 \%)\end{array}$ \\
\hline & $150 \mathrm{mg} / \mathrm{kg}$ & $\begin{array}{c}10.74 \pm 0.52^{*} \\
(13.72 \%)\end{array}$ & $\begin{array}{l}9.53 \pm 0.34^{*} \\
(22.64 \%)\end{array}$ & $\begin{array}{l}8.27 \pm 0.16^{*} \\
(32.54 \%)\end{array}$ & $\begin{array}{l}6.03 \pm 0.07^{\star * *} \\
(50.97 \%)\end{array}$ & $\begin{array}{l}4.65 \pm 0.06^{\star * *} \\
(59.56 \%)\end{array}$ \\
\hline & $200 \mathrm{mg} / \mathrm{kg}$ & $\begin{array}{c}11.10 \pm 0.43 \\
(10.83 \%)\end{array}$ & $\begin{array}{l}9.76 \pm 0.42^{*} \\
(20.77 \%)\end{array}$ & $\begin{array}{l}8.40 \pm 0.11^{*} \\
(31.48 \%)\end{array}$ & $\begin{array}{l}6.64 \pm 0.14^{\star * *} \\
(46.01 \%)\end{array}$ & $\begin{array}{l}4.45 \pm 0.04^{* * *} \\
(61.30 \%)\end{array}$ \\
\hline \multirow{4}{*}{ 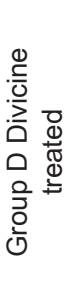 } & $50 \mathrm{mg} / \mathrm{kg}$ & $\begin{array}{c}11.53 \pm 0.45 \\
(7.38 \%)\end{array}$ & $\begin{array}{c}11.28 \pm 0.24 \\
(8.44 \%)\end{array}$ & $\begin{array}{c}10.73 \pm 0.47 \\
(12.47 \%)\end{array}$ & $\begin{array}{c}10.30 \pm 0.17 \\
(16.26 \%)\end{array}$ & $\begin{array}{l}9.46 \pm 0.32^{*} \\
(17.73 \%)\end{array}$ \\
\hline & $100 \mathrm{mg} / \mathrm{kg}$ & $\begin{array}{c}10.82 \pm 0.37^{*} \\
(13.09 \%)\end{array}$ & $\begin{array}{l}9.55 \pm 0.38^{*} \\
(22.48 \%)\end{array}$ & $\begin{array}{l}9.18 \pm 0.30^{*} \\
(25.12 \%)\end{array}$ & $\begin{array}{l}8.26 \pm 0.26^{*} \\
(32.84 \%)\end{array}$ & $\begin{array}{l}8.08 \pm 0.28^{* *} \\
(29.73 \%)\end{array}$ \\
\hline & $150 \mathrm{mg} / \mathrm{kg}$ & $\begin{array}{c}10.86 \pm 0.17^{*} \\
(12.77 \%)\end{array}$ & $\begin{array}{l}8.24 \pm 0.61^{*} \\
(31.65 \%)\end{array}$ & $\begin{array}{l}8.12 \pm 0.29^{*} \\
(33.76 \%)\end{array}$ & $\begin{array}{l}7.10 \pm 0.07^{* *} \\
(42.27 \%)\end{array}$ & $\begin{array}{l}6.25 \pm 0.2^{* * *} \\
(45.65 \%)\end{array}$ \\
\hline & $200 \mathrm{mg} / \mathrm{kg}$ & $\begin{array}{c}11.10 \pm 0.25 \\
(10.84 \%)\end{array}$ & $\begin{array}{l}8.14 \pm 0.15^{*} \\
(33.92 \%)\end{array}$ & $\begin{array}{l}8.15 \pm 0.33^{* *} \\
(33.52 \%)\end{array}$ & $\begin{array}{l}7.23 \pm 0.52^{* *} \\
(41.21 \%)\end{array}$ & $\begin{array}{l}6.28 \pm 0.37^{* * *} \\
(45.39 \%)\end{array}$ \\
\hline \multicolumn{2}{|c|}{$\begin{array}{c}\text { Group E (Diclofenac) } \\
(100 \mathrm{mg} / \mathrm{kg})\end{array}$} & $\begin{array}{c}11.89 \pm 0.03 \\
(4.49 \%) \\
\end{array}$ & $\begin{array}{c}4.43 \pm 0.05^{* * *} \\
(64.04 \%) \\
\end{array}$ & $\begin{array}{c}3.72 \pm 0.05^{* * *} \\
(69.65 \%) \\
\end{array}$ & $\begin{array}{c}2.44 \pm 0.04^{* * *} \\
(80.16 \%) \\
\end{array}$ & $\begin{array}{c}0.00 \pm 0.00^{* * *} \\
(100 \%) \\
\end{array}$ \\
\hline
\end{tabular}
used are indicated as \%

dose-related, significant $(\mathrm{p}<0.05-0.001)$ anti-inflammatory activity with the highest percentage inhibition $(59.56 \%)$ and $(45.65 \%)$ for vicine and divicine, respectively, at $150 \mathrm{mg} /$ $\mathrm{kg}$ against the fresh egg albumin-induced oedema in rats after $180 \mathrm{~min}$. Also, the standard anti-inflammatory diclofenac sodium $(100 \mathrm{mg} / \mathrm{kg})$ showed $100 \%$ inhibition against the fresh egg albumin-induced oedema in rats after 180 minutes (Table 4). Sub plantar injections of fresh egg albu$\min (0.5 \mathrm{ml} / \mathrm{kg})$ proved marked, time-related and progressive increases in the hind paw diameters of the 'control' untreated rats, maximal swelling and/or oedema occurred approximately 120 minutes following fresh egg albumin administration. Distilled water $(3 \mathrm{ml} / \mathrm{kg}$, orally) treatment alone had no any responses to the rat inflammatory oedema induced by fresh egg albumin administration.

\section{BIOCHEMICAL STUDIES OF VICINE AND DIVICINE}

Administration of vicine and divicine orally to the rats at doses of $50-150 \mathrm{mg} / \mathrm{kg}$ bw for 10 days showed non-significant 
Mohammed Abdalla Hussein: Anti-inflammatory effect of natural heterocycle glucoside vicine

Table 5 Levels of glutamic-oxaloacetic transaminase (GOT), glutamic-pyruvate transaminase (GPT), alkaline phosphatase (ALP), gamma glutamyl transferase ( $\gamma$-GT), lactate dehydrogenase (LDH) and lipid peroxides (TBARS) in serum of normal and experimental groups of rats

\begin{tabular}{|c|c|c|c|c|c|c|c|}
\hline & $\begin{array}{l}\text { ntal Group } \\
\text { (orally) }\end{array}$ & $\begin{array}{c}\text { SGOT } \\
\text { U/I }\end{array}$ & $\begin{array}{c}\text { SGPT } \\
\text { U/I }\end{array}$ & $\begin{array}{c}\text { ALP } \\
\text { U/I }\end{array}$ & $\begin{array}{c}\gamma-G T \\
U / I\end{array}$ & $\begin{array}{l}\text { LDH } \\
\text { U/I }\end{array}$ & $\begin{array}{c}\text { TBARs } \\
\mathrm{nmol} / \mathrm{ml}\end{array}$ \\
\hline \multicolumn{2}{|c|}{ Normal Group A (untreated) } & $12.45 \pm 2.24$ & $35.6 \pm 3.8$ & $42.4 \pm 5.33$ & $6.22 \pm 2.09$ & $247.36 \pm 7.18$ & $4.52 \pm 1.68$ \\
\hline \multicolumn{2}{|c|}{ Control Group B (Distilled water) } & $12.73 \pm 3.25$ & $34.65 \pm 6.11$ & $40.61 \pm 4.08$ & $6.20 \pm 1.66$ & $244.55 \pm 10.43$ & $4.43 \pm 2.1$ \\
\hline \multirow{4}{*}{ 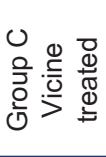 } & $50 \mathrm{mg} / \mathrm{kg}$ & $11.43 \pm 3.63$ & $37.12 \pm 5.07$ & $40.04 \pm 6.34$ & $6.13 \pm 1.47$ & $246.35 \pm 11.56$ & $4.51 \pm 0.58$ \\
\hline & $100 \mathrm{mg} / \mathrm{kg}$ & $11.87 \pm 1.45$ & $37.84 \pm 4.35$ & $45.80 \pm 6.23$ & $6.25 \pm 1.62$ & $249.54 \pm 9.97$ & $4.35 \pm 1.25$ \\
\hline & $150 \mathrm{mg} / \mathrm{kg}$ & $13.84 \pm 3.11$ & $39.76 \pm 6.54$ & $47.22 \pm 7.32$ & $6.49 \pm 2.00$ & $250.27 \pm 15.68$ & $4.54 \pm 0.88$ \\
\hline & $200 \mathrm{mg} / \mathrm{kg}$ & $15.92 \pm 3.61^{*}$ & $37.48 \pm 3.82$ & $48.4 \pm 4.76^{*}$ & $7.23 \pm 2.60^{*}$ & $255.73^{*} \pm 18.36$ & $4.12 \pm 0.81$ \\
\hline \multirow{4}{*}{ 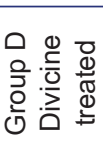 } & $50 \mathrm{mg} / \mathrm{kg}$ & $12.50 \pm 2.46$ & $36.54 \pm 6.05$ & $45.04 \pm 6.34$ & $6.27 \pm 2.08$ & $253.06 \pm 10.39$ & $4.47 \pm 0.82$ \\
\hline & $100 \mathrm{mg} / \mathrm{kg}$ & $13.10 \pm 3.12$ & $40.42 \pm 5.84$ & $50.80 \pm 6.23$ & $6.13 \pm 1.98$ & $245.44 \pm 14.60$ & $4.69 \pm 1.07$ \\
\hline & $150 \mathrm{mg} / \mathrm{kg}$ & $13.56 \pm 2.97$ & $39.11 \pm 4.33$ & $52.22 \pm 7.32$ & $6.06 \pm 2.67$ & $252.58 \pm 9.86$ & $4.72 \pm 1.34$ \\
\hline & $200 \mathrm{mg} / \mathrm{kg}$ & $14.34 \pm 4.11^{*}$ & $42.67 \pm 5.62$ * & $55.4 \pm 4.76^{*}$ & $6.10 \pm 2.85$ & $263.37 \pm 16.94^{*}$ & $4.45 \pm 0.96$ \\
\hline \multicolumn{2}{|c|}{ Group E (Diclofenac) (100 mg/kg) } & $29.76 \pm 4.29^{*}$ & $65.29 \pm 6.72^{*}$ & $70.32 \pm 5.11^{*}$ & $12.65 \pm 2.51^{*}$ & $310.55 \pm 13.73^{*}$ & $7.25 \pm 1.47^{*}$ \\
\hline
\end{tabular}

changes in liver enzymes SGOT, SGPT, ALP, LDH, $\gamma$-GT and serum TBARs as compared with the control group (Table 5). But oral administration of vicine and divicine at $200 \mathrm{mg} / \mathrm{kg}$ bw showed a significant increase $(\mathrm{p}<0.05)$ in liver SGOT, SGPT, ALP and LDH level. On the other hand, oral administration of diclofenac sodium (100 mg/ $\mathrm{kg} \mathrm{wb}$ ) showed significant increase of serum SGOT, SGPT, ALP, $\mathrm{LDH}, \gamma-\mathrm{GT}$ and TBARs as compared with the control group.

Table 6 shows the concentration of GSH, SOD and GPx in blood of normal and experimental groups of rats. The levels of GSH, SOD and GPx did not present significant changes in the groups treated with vicine (50-200) and divicine (50-150) $\mathrm{mg} / \mathrm{kg}$ bw as compared with the control group. But oral administration of divicine at $200 \mathrm{mg} / \mathrm{kg}$ bw showed a significant decrease $(p<0.05)$ in liver GSH, SOD and GPx level, as well as administration of diclofenac sodium orally at dose of $100 \mathrm{mg} / \mathrm{kg}$ bw showed a significant decrease of blood SOD, GPx and GSH as compared with the control group.

\section{LIVER TISSUE MORPHOLOGY}

The varying doses of vicine, divicine (50, 100, 150 and $200 \mathrm{mg} / \mathrm{kg} /$ day for 10 days) administered orally to rats for 10 days did not induce pathologic changes in the morphology of the liver cells of the test animals. Also, oral administration of diclofenac sodium to rats for 10 days $(100 \mathrm{mg} /$ $\mathrm{kg} / \mathrm{d}$ ) shows pronounced dilatation of the hepatic portal vein (Figure 2) as compared with control (Figure 3).

\section{DISCUSSION}

Vicine [2,6-diamino-5-( $\beta$-D-glucopyranosyloxy)-4(1H)pyrimidinone] and its aglycones divicine [2,6- diamino1,6-dihydro-4,5-pyrimidinedione] are natural biologically active plant products (Figure 1). Vicine and/or divicine were detected in various species of family Fabaceae: Vicia sativa L. ${ }^{[39]}$ and Vicia faba L. ${ }^{[40]}$ Vicine was found also in Pisum sativum L. ${ }^{[4]}$ and in Lupinus albus L. ${ }^{[42]}$ Lupinus

Table 6 Level of reduced glutathione (GSH) and activities of superoxide dismutase (SOD) and glutathione peroxidase (GPx) in blood of normal and experimental groups of rats

\begin{tabular}{|c|c|c|c|c|}
\hline \multicolumn{2}{|c|}{ Experimental Group Dose (orally) } & GSH (mg \%) & SOD (U/g Hb) & GPx (U/g Hb) \\
\hline \multicolumn{2}{|c|}{ Normal Group A (untreated) } & $59.48 \pm 5.32$ & $15.17 \pm 2.64$ & $163.95 \pm 10.72$ \\
\hline \multicolumn{2}{|c|}{ Control Group B (distilled water) } & $62.75 \pm 5.42$ & $15.35 \pm 2.48$ & $160.85 \pm 7.66$ \\
\hline \multirow{4}{*}{ 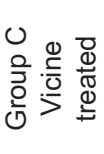 } & $50 \mathrm{mg} / \mathrm{kg}$ & $58.37 \pm 6.18$ & $14.90 \pm 3.05$ & $165.26 \pm 9.76$ \\
\hline & $100 \mathrm{mg} / \mathrm{kg}$ & $59.26 \pm 5.08$ & $14.75 \pm 2.74$ & $160.14 \pm 12.33$ \\
\hline & $150 \mathrm{mg} / \mathrm{kg}$ & $55.72 \pm 8.47$ & $14.56 \pm 4.27$ & $155.48 \pm 13.52$ \\
\hline & $200 \mathrm{mg} / \mathrm{kg}$ & $56.43 \pm 5.76$ & $14.28 \pm 2.11$ & $159.75 \pm 17.30$ \\
\hline \multirow{4}{*}{ 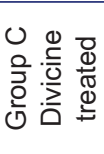 } & $50 \mathrm{mg} / \mathrm{kg}$ & $57.15 \pm 3.85$ & $14.76 \pm 1.93$ & $159.08 \pm 9.46$ \\
\hline & $100 \mathrm{mg} / \mathrm{kg}$ & $55.96 \pm 6.15$ & $14.10 \pm 1.57$ & $157.70 \pm 19.13$ \\
\hline & $150 \mathrm{mg} / \mathrm{kg}$ & $55.60 \pm 4.90$ & $13.73 \pm 2.76$ & $156.10 \pm 8.97$ \\
\hline & $200 \mathrm{mg} / \mathrm{kg}$ & $52.5 \pm 5.39^{*}$ & $11.65 \pm 2.05^{*}$ & $150.63 \pm 11.63^{*}$ \\
\hline \multicolumn{2}{|c|}{ Group E (Diclofenac) (100 mg/kg) } & $45.32 \pm 4.56^{*}$ & $9.58 \pm 2.56^{*}$ & $130.19 \pm 15.38^{*}$ \\
\hline
\end{tabular}




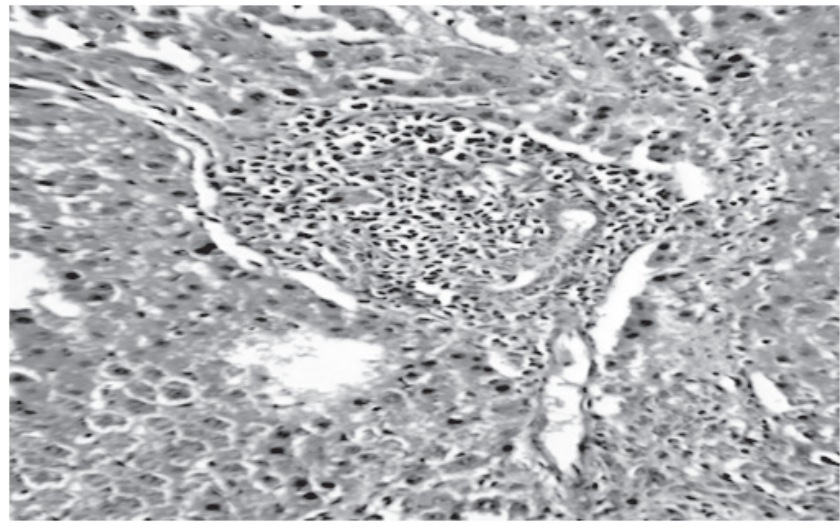

Figure 2. Photomicrograph of the cross section of liver from rat treated with diclofenac sodium $100 \mathrm{mg} / \mathrm{kg} / \mathrm{d}$ for 10 days (H\&E ). Shows pronounced dilatation of the hepatic portal vein $(\mathrm{x} 100)$.

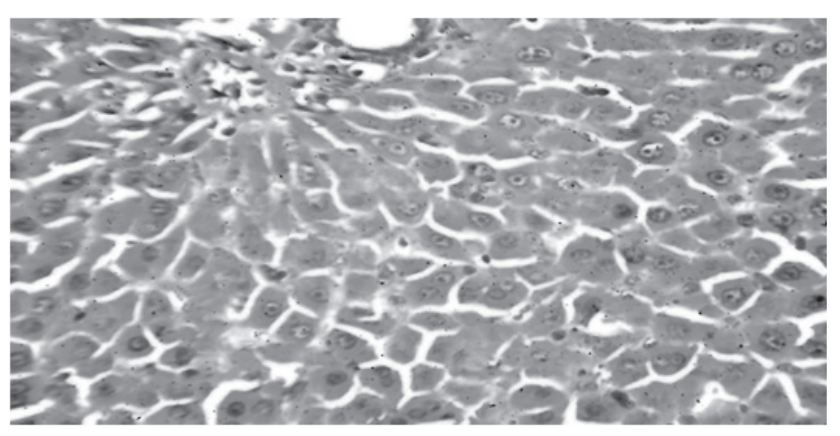

Figure 3. Photomicrograph of the cross section of liver of rat treated with normal distilled water daily for 10 days as control (H\&E). Shows normal hepatic portal vein (x100).

species has been reported in a previous study as effective in the treatment of chronic eczema. ${ }^{[43]}$ Some lupinus species exhibit anti-inflammatory capacity related mainly with the presence of phenolic compounds. ${ }^{[4]}$ As part of a program aimed at evaluating the anti-inflammatory activity of Vicia faba L. phenolic compounds; vicine and divicine and study their effect on serum and blood liver enzymes levels in albino rats.

\section{ISOLATION AND STRUCTURE ELUCIDATION OF VICINE AND DIVICINE}

This study has investigated a possible method to isolate the active phenolic compound; Vicine from Fava beans (Vicia faba) ${ }^{[22]}$ and by hydrolysing it, its aglucone divicine was obtained. ${ }^{[23]}$ Structure elucidation of vicine and divicine were established based on both elemental analysis and spectral data. Infrared spectrum of vicine indicated the presence of $\left(\mathrm{NH}_{2}\right),(\mathrm{OH}),(\mathrm{CH}$-aliphatic $),(\mathrm{C}=\mathrm{N}),(\mathrm{C}-\mathrm{O}-\mathrm{C})$ and $(\mathrm{C}-\mathrm{O}-\mathrm{C})$ groups. Mass spectrum of vicine revealed a molecular ion peak at $\mathrm{m} / \mathrm{z} 304(100 \%)$. The value of this peak in mass spectroscopy instrumental equals the elemental analysis data which equals the calculated molecular weight of vicine.

Infrared spectrum of divicine exhibited bands of $\left(\mathrm{NH}_{2}\right)$, (CH-aliphatic), $(\mathrm{C}=\mathrm{N}),(\mathrm{C}-\mathrm{O}-\mathrm{C})$ and $(\mathrm{C}-\mathrm{O}-\mathrm{C})$. Mass spectrum of divicine revealed a molecular ion peak and a base peak at m/z $143\left(\mathrm{M}^{+}+\mathrm{H}, 100 \%\right)$. The value of this peak in mass spectroscopy instrumental equals the elemental analysis data which equals the calculated molecular weight of divicine. Also, mass spectrum and elemental analysis of divicine indicated the breakdown of glycosidic bond in vicine by hydrolysis and lost one glucose moiety.

\section{DETERMINATION OF THE MEDIAN LETHAL DOSES $\left(\right.$ LD $\left._{50}\right)$ OF VICINE AND DIVICINE}

The symptoms, histopathological changes and death of experimental rats shown in this study were obviously due to acute toxicity caused by the oral administration of vicine and divicine. Fava beans (Vicia faba), from which the vicine and divicine were isolated, has been known to be a strong hypoglycemic agent. ${ }^{[43]}$ According to Deschroches et al., ${ }^{[45]}$ the $\mathrm{LD}_{50}$ data of vicine and its aglycone (divicine) 24 hours after intraperitoneal administration was $4000 \mathrm{mg} / \mathrm{kg}$ for vicine and $149 \mathrm{mg} / \mathrm{kg}$ for divicine related to the body weight of rats. In this study, the median lethal doses $\left(\mathrm{LD}_{50}\right)$ of vicine and its aglucone (divicine) 24 hours after oral administration were $2100 \mathrm{mg} / \mathrm{kg}$ for vicine and $1950 \mathrm{mg} /$ $\mathrm{kg}$ for divicine (Tables 2 and 3). The median lethal doses $\left(\mathrm{LD}_{50}\right)$ of vicine and its aglucone (divicine) after oral administration have not been reported earlier to my knowledge, and this study is perhaps the first observation of its kind. The experimental animals could be classified into three categories: 1) animals that died early within the first few hours of ingestion; 2) animals that died later within the observation period (up to 48 hours); 3) animals that exhibited mild symptoms but were able to survive. Possible causes of death are heart failure that can occur by malfunction, ${ }^{[46]}$ acute hypoglycaemia and hepato-damage. The immediate cause of death of animals that died early was probably heart failure. According to Kingsbury, at toxic levels, cardioactive glycosides produce cardiac irregularities and heart block. ${ }^{[4]}$ Furthermore, in many lethal poisonings, heart failure can be brought about by malfunction of innervation or of the heart's conductive tissues, or it may be a result of a more direct effect on the heart musculature. As time after ingestion goes on, the glycosides have enough time to exert its action and death is likely to be due to acute hypoglycaemia rather than heart failure. 


\section{Mohammed Abdalla Hussein: Anti-inflammatory effect of natural heterocycle glucoside vicine}

This probably explains the death of the animals that died later, since hypoglycaemia was confirmed in these animals by blood test. ${ }^{[48]}$ Hepato-damage, seen in the animals that died later, is another possible cause of death, although apparently overshadowed by the acute hypoglycaemia. ${ }^{[43]}$ The animals that survived escaped heart failure and acute hypoglycaemia and were also able to overcome hepatodamage by regeneration.

\section{SCREENING OF ANTI-INFLAMMATORY ACTIVITY OF VICINE AND DIVICINE}

The anti-inflammatory activities of the agent under study were investigated by using the fresh egg albumin-induced edema model described by Ekpendu et al. ${ }^{[33]}$ The finding of anti-inflammatory activity exerted by vicine and divicine and the identification of active principles could support the use of these compounds for the treatment of inflammatory affections. The results obtained show that the effect exerted by vicine is higher than that exhibited by divicine. Previous studies concerning the mechanism of action of phenolic compounds as anti-inflammatory agent were shown that phenolics have anti-inflammatory activity in both proliferative and exudative phases of inflammation ${ }^{[4,50]}$ while the mechanism of action of vicine and divicine as anti inflammatory agent may be due to the inhibition of some enzymes which participate in the synthesis of inflammatory substances derived from arachidonic acid. ${ }^{[50]}$ Pyrimidines like vicine and divicine represent a broad class of compounds, which have received considerable attention due to their wide range of biological activities, ${ }^{[51]}$ inhibit both the cyclooxygenase and 5-lipoxygenase pathways. ${ }^{[5]}$ This inhibition reduces the release of arachidonic acid. Another anti-inflammatory property of phenolics is their suggested ability to inhibit neutrophil degranulation. This is a direct way to diminish the release of arachidonic acid by neutrophils and other immune cells. ${ }^{[33]}$ The used dose of diclofenac sodium in this work was reported ${ }^{[25,26,54]}$ and the results showed that diclofenac sodium enhanced the activity of liver enzymes. This finding suggests increased transmembrane transport of diclofenac sodium and metabolized it in the liver to 4-hydroxy diclofenac and other hydroxylated forms after glucoronidation and sulfation before being eliminated principally via urinary and biliary excretions, ${ }^{[55]}$ where liver enzymes, especially, alkaline phosphatase, are involved in the absorption and transportation across canalicular membrane proteins. ${ }^{[5]}$ On the other hand, alkaline phosphatase is a meta-enzyme and contains zinc as an integral part. ${ }^{[57]}$ The nonspecific increase in the activity of alkaline phosphatase by diclofenac sodium exposure may be a result of the incorporation of the drug in the place of zinc atoms leading to an increase in the activity of this enzyme. ${ }^{[58]}$ Hence, the present results might suggest a possible role of this enzyme in the catabolism of nucleic acids in the cells disintegrated by diclofenac sodium effect. The anti-inflammatory effect of vicine and its aglucone (divicine) after oral administration has not been reported earlier to my knowledge, and this study is perhaps the first observation of its kind.

\section{EFFECT OF ANTI-INFLAMMATORY COMPOUNDS ON LIVER ENZYME LEVELS}

Investigation of the effects of administration of vicine and divicine $(50-150 \mathrm{mg} / \mathrm{kg} \mathrm{bw})$ isolated from fava beans (Vicia faba) on the serum levels of AST, ALT, $\gamma$-GT, and TBARS and levels of blood GSH, SOD and GPx in normal and experimental groups of rats revealed that acute treatments for 10 days resulted in a non significant rise in the serum and blood enzyme levels. The sharp significant increase was attenuated gradually after repeated administration of vicine and divicine $(200 \mathrm{mg} / \mathrm{kg} \mathrm{bw})$ a period of 10 days. On the other hand, vicine (50-200 $\mathrm{mg} / \mathrm{kg}$ ) and divicine $(50-150 \mathrm{mg} / \mathrm{kg}$ ) treatment for 10 days caused a non significant reduction in the blood levels of GSH, SOD and GPx, respectively. But oral administration of divicine at $200 \mathrm{mg} / \mathrm{kg}$ bw, caused a significant reduction $(p<0.05)$ in the blood levels of GSH, SOD and GPx. Also, the sharp significant rise of serum levels of AST, ALT, $\gamma-G T$ and TBARS and significant decreased in levels of blood GSH, SOD and GPx after repeated administration of diclofenac sodium ( $100 \mathrm{mg} / \mathrm{kg}$ orally) for a period of 10 days were reported. In addition, the photomicrograph of the cross section of liver from a rat treated with diclofenac sodium $100 \mathrm{mg} / \mathrm{kg} / \mathrm{d}$ for 10 days shows pronounced dilatation of the hepatic portal vein. Graded non significant increase in serum and blood enzymes activity after treatment for 10 days might be an indication of negative feedback effect. This phenomenon was similar to the negative feedback mechanism involving the release of hormones. ${ }^{[59]}$ Also, a sharp rise in the enzyme serum levels could probably be due to sudden physiological changes following acute vicine and divicine tissue interaction and not necessarily pathological. It has been reported that some substances are capable of inducing enzymes such as cytochrome P-450, monooxygenase, monoamine oxidase and other enzymes. ${ }^{[60,61]}$ These observations showed that repeated administration of vicine and divicine isolated from fava beans (Vicia faba) could stimulate the release of some enzymes into serum which could influence extrahephatic metabolism of 


\section{Mohammed Abdalla Hussein: Anti-inflammatory effect of natural heterocycle glucoside vicine}

certain substances or drug biotransformation. Repeated administration of vicine and divicine for 10 days almost did not cause any significant change in serum and blood enzyme levels. These findings led to the suggestion that vicine and divicine isolated from fava beans (Vicia faba) is not like to be hepatotoxic. Finally, anti-inflammatory effect of natural heterocycle glucoside vicine obtained from Vicia faba L. and its aglucone (divicine) and their effect on serum and blood enzyme levels in Albino rats have not been reported earlier to my knowledge, and this study is perhaps the first observation of its kind.

In conclusion, the present study showed that vicine obtained from Vicia faba L. and its aglucone divicine have a considerable anti-inflammatory activity. Further studies are in progress to identify the possible mechanism of their effect.

\section{REFERENCES}

1. Amir M, Javed SA, Kumar H. Pyrimidine as anti-inflammatory agent: a review. Indian J. Pharm. Sciences. 2007; 3:337-43.

2. Cox RA. Macromolecular structure and properties of ribonucleic acids. Quart. Rev. 1968; 22:499-510.

3. Raghav M, Isha T. Pyrimidine: the molecule of diverse biological and medicinal importance. IJPSR, 2011; 4:758-71.

4. Jain KS, Chitre T, Miniyar B, Kathiravan M, Bendre S, Veer S, et al. Biological and medicinal significance of pyrimidine. Current Sciences. 2006; 6:793-805.

5. Mohammad A, Sadique A, Harish K. Synthesis and biological evaluation of some 4-(1H-indol-3-yl)-6-phenyl-1,2,3,4-tetrahydropyrimidin-2-ones/thiones as potent anti-inflammatory agents. Acta Pharm. 2008; 58:467-77.

6. Sondhi SM, Singh N, Johar M, Kumar A. Synthesis, anti-inflammatory and analgesic activities evaluation of some mono, bi and tricyclic pyrimidine derivatives. ,Bioorg. Med. Chem. 2005; 13:6158-66.

7. Bjerg B, Knudsen J,Olsen O, Poulsen M, Soerensen H. Quantitative analysis and inheritance of vicine and convicine content in seeds of Vicia faba L. Z. Pfl.- Zücht 1985; 94:135-48.

8. Yalcin SI, Tuncer I, Yalcin S, Onbacilar E. The use of different levels of common vetch seed (Vicia sativa L.) in diets for fattening rabbits. Livest. Prod. Sci. 2003; 84:93-7.

9. El.Gengaihi S, Karawya MS, Motawe HM, Selim MA, Ibrahim N, Faddah LM. A novel pyrimidine glycoside from Momordica charantia L. Pharmazie. 1995; 50:361-2.

10. Raman A, Lau C. Anti diabetic activity properties and phytochemistry of Momordica charantia Linn. Phytomedicine. 1996; 2:(4)349-62.

11. Sigmeth W, Sieberer W. A comparision of the short-term effects of ibuprofen and diclofenac sodium in spondylosis. Journal of International Medical Research. 6:369-74.

12. Brooks PM, Hill W, Geddes R. Diclofenac sodium and ibuprofen in rheumatoid arthritis and osteoarthritis. Medical Journal of Australia. 1980; 1:29-30.

13. Small RE. Drug reviews: diclofenac sodium. Clinical Pharmacy. 1989; 8:545-58

14. Todd PA, Sorkin EM. Diclofenac sodium: a reappraisal of its pharmacodynamic and pharmacokinetic properties and therapeutic efficacy. Drugs. 1988; 35:244-85.

15. Skoutakis VA, Carter CA, Mickle TR, Smith V H, Arkin CR, Alissandratos J. Review of diclofenac sodium and evaluation of its place in therapy as a non-steroidal anti-inflammatory agent. Drug Intelligence and Clinical Pharmacy. 1988; 22: 850-9.

16. Friman C, Johnston C, Chew C, Davis P. Effect of diclofenac sodium, tolfenamic acid and indomethacin on the production of superoxide induced by $\mathrm{N}$-formyl-methionyl-leucylphenylalanine in normal human polymorphonuclear leukocytes. Scandinavian Journal of Rheumatology. 1986; 15:41-6.
17. Al-Tuwaijri AS, Mustafa AA. Verapamil enhances the inhibitory effect of diclofenac sodium on the chemiluminescence of human polymorphonuclear leukocytes and carrageenan-induced rat's paw oedema. International Journal of Immunopharmacology. 1992; 14:83-91.

18. Hussein MA. Antidiabetic and antioxidant activity of Jasonia Montana extract in streptozotocin-induced diabetic rats. Saudi Pharmaceutical Journal. 2008; 16:214-21.

19. Hussein MA, Abdel-Gawad SA. Protective effect of Jasonia montan against ethinylestradiol-induced cholestasis in rats. Saudi Pharmaceutical Journal. 2010; 18:35-45.

20. Hussein MA, Farghaly HS. Protective effects of Jasonia montana against Lipid peroxidation in liver and kidney of iron-overloaded rats. Australian Journal of Basic and Applied Sciences. 2010; 4:2004-12.

21. Hussein MA. Anti-obesity, antiatherogenic, anti-diabetic and antioxidant activities of $\mathrm{J}$. montana ethanolic formulation in obese diabetic rats fed high-fat diet. Free Radicals and Antioxidants. 2011; 1:51-62.

22. Arbid MSS, Marquardt RR. Hydrolysis of the toxic constituents (vicine and convicine) in fava bean (Vicia faba L.) food preparations following treatment with $\beta$-glucosidase. J Sci Food Agric. 1985; 36:839-46.

23. Marquardt R, Muduuli D, Frohlish A. Purification and some properties of vicine and convicine isolated from fava beans (Vicia faba L.) protein concentrate. Journal of Agriculture and Food Science. 1983; 31:839-44.

24. Finney DJ. Statistical methods in biological assay. Charles Griffen \& Company Ltd. London; 1964.

25. Ojewole JA. Evaluation of the analgesic, anti-inflammatory and anti-diabetic properties of Sclerocarya birrea (A. Rich.) Hochst. stem-bark aqueous extract in mice and rats. Phytother Res. 2004; 8:601-8.

26. Alam MA, Haque MA, Shilpi JA, Daulla KA. Antinocieptive effect of the crude effect of the crude ethanolic extract of Crataeva nurvala Buch on mice. Bangl. J. Vet. Med. 2006; 4:65-8.

27. Mahmoud AK, Hussein MA, Samir MO, Alaa El-Haddad. Anti-inflammatory and antioxidant activities of Moringa peregrina seeds. Free Radicals and Antioxidants. 2011; 1:49-61.

28. Hussein MA. Synthesis of some novel triazoloquinazolines and triazinoquinazolines and their evaluation for anti-inflammatory activity. Medicinal Chemistry Research. 2011; DOI: 10.1007/s00044-011-9707-0.

29. Lavergne N, Volkman M, Maki JE, Yoder R, Trepanier A. Evaluation of the clinical, immunologic, and biochemical effects of nitroso sulfamethoxazole administration to dogs. Toxicology. 2005; 208:63-72.

30. Reitman S, Frankel A. A colorimetric method for the determination of serum glutamic oxaloacetic acid and glutamic pyruvic transaminases. Am J Clin Pathol. 1975; 28:56-62.

31. King EJ, Armstrong AR. Calcium, phosphorus and phosphate. In Practical Clinical Biochemistry. Edited by: Varley H. New Delhi: CBS Publishers. 1988; p 458.

32. Fiala S, Fiala AE, Dixon B. Gamma glutamyl transpeptidase in transplantable chemically induced rat hepatomas and spontaneous mouse hepatomas. J Nat Can Inst. 1972; 48:1393.

33. Buhl SN, Jackson KY. Optimal conditions and comparison of lactate dehydrogenase catalysis of the lactate to pyruvate to lactate reactions in human serum at 25,30 and $37^{\circ} \mathrm{C}$. Clin. Chem. 1978; 2415:828-35.

34. Uchiyama M, Mihara M. Determination of malondialdehyde precursor in tissues by thiobarbituric acid test. Anal. Biochem. 1978; 86:271.

35. Paglia D, Valentine W. Studies on the quantitative and qualitative characterization of erythrocyte glutathione peroxidase. J. Lab. Clin. Med. 1967; 70:158-64

36. Marklund S, Marklund D. Involvement of the superoxide anion radical in the autoxidation of pyrogallol and a convenient assay for superoxide dismutase. Eur. J. Biochem. 1974; 47:469-76.

37. VanKampen E, Zijlstra W. Standardization of hemoglobinometry II. The hemiglobin-cyanide method. Clin. Chim. Acta. 1961; 6:538-43.

38. Bancroft G, Steven A. In. Theory and Practice of Histological Technique $4^{\text {th }}$ Ed. Churchill Livingstone. 1983; pp. 99-112; London.

39. Ritthausen $\mathrm{H}$. Ueber Vicin. Bestandtheil der Samen von Vicia sativa. Ber Dtsch. Chem. Ges.1876; 9:301-4.

40. Brown E, Roberts F. Formation of vicine and convicine by Vicia faba. Phytochemistry, 1972; 11:3203-06.

41. Jamalian J, Ayward F, Hudson BJF. Favism-inducing toxins in broad beans (Vicia faba): estimation of the vicine contents of broad bean and other legume samples. Qual. Plant. Plant Foods Hum. Nutr.1977; 27:207-11.

42. Pompei C, Lucisano M. Le lupin (Lupinus albus L.) comme source de protéines pourl'alimentation humaine. I. Etude préliminaire. Lebensm.-Wiss. Technol. 1976; 9:289-95. 


\section{Mohammed Abdalla Hussein: Anti-inflammatory effect of natural heterocycle glucoside vicine}

43. Lampart-Szczapa E, Siger A Trojanowska K, Nogala-Kalucka M, Malecka M, Pacholek B. Chemical composition and antibacterial activities of lupin seeds extracts. Nahrung Food. 2003; 47:286-90.

44. Hamzah MM. Evaluation of topical preparations containing curcuma, acacia and lupinus extracts as an antiinflammatory drugs. International Journal of Applied Research in Natural Products. 2011; 2:19-23.

45. Deschroches P, El Shazly E, Mandon N, Duc G, Huignard J. Development of Callosobruchus chinensis L. and C. maculatus F. (Coleoptera: Bruchidae) in seeds of Vicia faba L. differing in their tannin, vicine and convicine contents. J. Stored Prod. Res., 1995; 31:83-9.

46. Diwan FH, Abdel-Hassan A, Mohammed ST. Effect of saponin on mortality and histopathological changes in mice. Eastern Mediterranean Health Journal. 2000; 6:345-51.

47. Kingsbury JM. Phytotoxicology. In: Doull J, Klaassen GD, Amdour MO. Casarett and Doull's toxicology: the basic science of poisons. New York, MacMillan Publishing Company, 1980:578-90.

48. Elawad AA. The effect of Citrullus colocynthis on sheep. Journal of veterinary and human toxicology. 1984, 26:481-5.

49. Faraj A, Vasanthan T. Soybean isoflavones: effects of processing and health benefits. Food Reviews International. 2004; 20:51-75.

50. Genovese I, Barbosa.L, Pinto, Lajolo FM. Commercial soy protein ingredients as isoflavones sources for functional foods. Plants Foods for Human Nutrition. 2007; 62:53-8.

51. Amit R, Dipti K, Naresh R, Viresh H. Synthesis and biological evaluation of some new pyrimidines via a novel chalcone series. ARKIVOC. 2008; xi: 131-41.

52. Zienab M, Hoda H, Eman S, Wafaa E. Synthesis of new pyrimidine derivatives with evaluation of their anti-inflammatory and analgesic activities. Acta Poloniae Pharmaceutica ñ Drug Research. 2011; 4:507-17.
53. Rathee $\mathrm{P}$, Chaudhary $\mathrm{H}$, Rathee $\mathrm{S}$, Rathee D, Kumar V, KohliK. Mechanism of action of flavonoids as anti-inflammatory agents: a review. Inflamm Allergy Drug Targets. 2009; 3:229-35.

54. Ferrandiz M, Alcaraz M. Anti-inflammatory activity and inhibition of arachidonic acid metabolism by flavonoids. Agents Actions. 1991; 32:283-8.

55. Tang W, Stearns R, Banndiera S. Studies on cytochrome P-450 mediated bioactivation of declofenac in ratsand human hepatocytes: identification of glutathione conjugated metabolites. Drug Metabol. Dispos. 1999; 3:365-71

56. Venkatesh P, Pandeya SN. Synthesis and anti-inflammatory activity of some novel 2,4-diaryl-3,5-bis(arylimino)- 1,2,4-thiadiazolidine derivatives. E-Journal of Chemistry. 2009; 6:(2)495-503.

57. Sandhir R, Gill K. Effect of Lead on Lipid Peroxidation in Liver of Rat." Biological Trace Element Research, 1995; 48: 91-7.

59. Noory T, Bashir M. Histochemical alterations in the spleen of rabbits induced by diclofenac sodium (Voltaren). J. King Saud Univ. 2006; $1: 21-9$.

60. Boyer D. P. The Enzymes. 3rd ed., New York: Academic Press, 1971.

61. Bowman C, R and M. (1980). The endocrine system and drug affecting endocrine function. In W. C. Bowman and M. J. Rand (Eds), Textbook of Pharmacology (2nd ed) (P19. 1-64). Oxford: Blackwell Scientific Publications.

62. DiBiase A R, Colechia A, Scaioli E, Berii R, Viola L, Vestito A,. Autoimmune liver diseases in a paediatric population with coelioic disease a 10-year single centre experience. International Journal of Gastroenterology and Hepatology. 2010; 31:(2)253-9. 